\title{
APPLICATION OF HEALTH BELIEF MODEL AND THEORY OF PLANNED BEHAVIOR ON FACTORS AFFECTING BREAST SELF EXAMINATION AMONG UNIVERSITY STUDENTS
}

\author{
Asruria Sani Fajriah1), Supriyadi Hari Respati²), Bhisma Murti') \\ 1)Masters Program in Public Health, Universitas Sebelas Maret \\ 2)Department of Obstetrics and Gynecology, Dr. Moewardi Hospital, Surakarta
}

\begin{abstract}
Background: Breast self-examination (BSE) is a technique that allows a woman to examine her breast tissue for any physical or visual changes. It is important to help women in the early detection of breast abnormality. This study aimed to determine factors affecting breast self examination among university students using health belief model and theory of planned behavior.

Subjects and Method: A cross-sectional study was conducted in Universitas Sebelas Maret, from August to September 2019. A sample of 200 female collage students was selected by simple random sampling. The dependent variable was breast-self examination. The independent variables were knowledge, perceived benefit, perceived barrier, intention, attitude, self-efficacy, cues to action, and subjective norm. The data were collected by questionnaire and analyzed by path analysis run on Stata 13 .

Results: BSE was directly increased by strong intention $(b=1.39 ; 95 \% \mathrm{CI}=0.58$ to 2.21; $\mathrm{p}=0.001)$, strong self-efficacy $(\mathrm{b}=1.53 ; 95 \% \mathrm{CI}=0.75$ to $2.30 ; \mathrm{p}<0.001)$, and strong cues to action $(\mathrm{b}=1.34 ; 95 \% \mathrm{CI}=0.56$ to $2.11 ; \mathrm{p}=0.001)$. BSE was indirectly affected by attitude, cues to action, perceived barrier, perceived benefit, subjective norm, and knowledge.

Conclusion: BSE was directly increased by strong intention $(b=1.39 ; 95 \% \mathrm{CI}=0.58$ to 2.21; $\mathrm{p}=0.001)$, strong self-efficacy $(\mathrm{b}=1.53 ; 95 \% \mathrm{CI}=0.75$ to $2.30 ; \mathrm{p}<0.001)$, and strong cues to action $(b=1.34 ; 95 \% \mathrm{CI}=0.56$ to $2.11 ; \mathrm{p}=0.001)$. BSE was indirectly affected by attitude, cues to action, perceived barrier, perceived benefit, subjective norm, and knowledge
\end{abstract}

Keywords: breast cancer, breast self examination, path analysis

\section{Correspondence:}

Asruria Sani Fajriah. Masters Program in Public Health, Universitas Sebelas Maret. Jl. Ir. Sutami 36A, Surakarta 57126, Central Java, Indonesia. Email: sanifajriah@gmail.com. Mobile: +6285790341801 .

The $7^{\text {th }}$ International Conference on Public Health Solo, Indonesia, November 18-19, 2020 | 153 https://doi.org/10.26911/the7thicph.02.42 